\title{
Fermentation Characteristics of Rice Crop Residue-Based Silage Treated by Epiphytic and Commercial LAB
}

\author{
B. Santoso*, a , B. Tj. Hariadi ${ }^{\mathrm{a}}$, Alimuddin ${ }^{\mathrm{b}}$, \& D. Y. Seseray ${ }^{\mathrm{c}}$ \\ aDepartment of Animal Nutrition, Faculty of Animal Science, Fishery and Marine Science, State University of Papua \\ bPapua Barat Assessment Institute for Agricultural Technology, Manokwari \\ 'Department of Animal Production, Faculty of Animal Science, Fishery and Marine Science, State University of Papua \\ Jln. Gunung Salju, Amban, Manokwari-Papua Barat, Indonesia \\ (Received 28-10-2011; accepted 21-02-2012)
}

\begin{abstract}
ABSTRAK
Dua percobaan dilakukan untuk mengetahui pengaruh penambahan inokulan bakteri asam laktat (BAL) yang berasal dari rumput raja dan inokulan komersil L. plantarum terhadap karakteristik fermentasi dan kecernaan silase berbasis sisa tanaman padi. Percobaan 1, campuran sisa tanaman padi (TP), ampas tahu (AT) dan onggok (OG) dengan rasio 80 : 10 : 10 berdasarkan bahan kering (BK) digunakan sebagai digunakan sebagai bahan silase. Empat perlakuan silase, yaitu (A) TP + AT + OG sebagai kontrol; (B) TP + AT + OG + 2\% (v/b) inokulan BAL berasal dari rumput raja; (C) TP + AT + OG $+3 \%(\mathrm{v} / \mathrm{b})$ inokulan BAL berasal dari rumput raja; (D) TP + AT + OG + 2\% (v/b) inokulan L. plantarum. Percobaan 2, sebanyak 6 ekor kambing kacang digunakan dalam rancangan bujur sangkar Youden $6 \times$ 3 dan diberi pakan rumput gajah, jerami padi, dan silase berbasis sisa tanam-an padi. Hasil penelitian menunjukkan bahwa silase B, C, dan D mengandung protein kasar (PK) lebih tinggi dibandingkan silase $\mathrm{A}$. Konsentrasi asam laktat lebih tinggi $(\mathrm{P}<0,01)$ pada silase $\mathrm{B}$ dan $\mathrm{C}$ dibandingkan silase D. Nilai $\mathrm{pH}$ pada silase A lebih tinggi $(\mathrm{P}<0,05)$ dibandingkan silase dengan perlakuan inokulan $B A L$. Kecernaan BK, bahan organik, dan PK silase sisa tanaman padi lebih tinggi $(\mathbf{P}<0,01)$ dibandingkan jerami padi. Disimpulkan bahwa penambahan BAL epifit dari rumput raja pada sisa tanaman padi menghasilkan kualitas fermentasi yang lebih baik dibandingkan inokulan L. plantarum.
\end{abstract}

Kata kunci: silase, sisa tanaman padi, bakteri asam laktat, kecernaan

\section{ABSTRACT}

Two experiments were conducted to investigate the effects of addition of lactic acid bacteria (LAB) inoculant from king grass and a commercial inoculant of L. plantarum on fermentation characteristics and nutrient digestibility of rice crop residue-based silage. In experiment 1 , mixture of rice crop residue $(\mathrm{RC})$, soybean curd residue (SC) and cassava waste $(\mathrm{CW})$ in a $80: 10: 10$ (on dry matter basis) ratio was used as silage material. Four treatments silage were (A) $R C+S C+C W$ as a control; (B) $R C$ $+\mathrm{SC}+\mathrm{CW}+\mathrm{LAB}$ inoculant from king grass $(2 \%, \mathrm{v} / \mathrm{w}) ;(\mathrm{C}) \mathrm{RC}+\mathrm{SC}+\mathrm{CW}+\mathrm{LAB}$ inoculant from king grass $(3 \%, \mathrm{v} / \mathrm{w}) ;(\mathrm{D}) \mathrm{RC}+\mathrm{SC}+\mathrm{CW}+\mathrm{L}$. plantarum inoculant $(2 \%$, v/w). In experiment 2 , six Kacang goats were used in a $6 \times 3$ Youden square experiment and fed elephant grass, rice straw, and rice crop residue-based silage. The results showed that crude protein $(\mathrm{CP})$ content in silages $B, C$, and D was slightly higher than silage $A$. Lactic acid concentration was significantly higher $(P<0.01)$ in silages $B$ and $C$ compared to silage $D$. The $\mathrm{pH}$ value of control silage $(A)$ was higher $(\mathrm{P}<0.05)$ than silage treated with LAB inoculant. Rice crop residue-based silage had higher $(P<0.01)$ digestibility of dry matter $(\mathrm{DM})$, organic matter $(\mathrm{OM})$, and $\mathrm{CP}$ than rice straw. It was concluded that addition of epiphytic LAB inoculant from king grass to rice crop residue resulting in a good fermentation quality of silage compared to addition of L. plantarum inoculant.

Key words: silage, rice crop residue, lactic acid bacteria, digestibility

\footnotetext{
* Corresponding author:
}

E-mail: santosob@lycos.com 


\section{INTRODUCTION}

In line with the shortage of grasses as a result of the change of land for plantations, housing and industry, it would require many efforts to utilize agricultural and food processing industry residues as feed source for ruminant. Recently, there is growing interest in the use of agricultural and food processing industry residues as silage materials. Ensiling is regarded as a good forage preservation method which has been widely used for many years, since fermentation by some microbes is an effective way to improve the digestibility, palatability and nutritive value of straws (Nishino et al., 2004; Gao et al., 2008). Ruminants fed silage may have a number of beneficial effects due to conversion lactic acid into propionic acid which is the precursor of gluconeogenesis (McDonald et al., 1987) and probiotic effect of the lactic acid bacteria (LAB) used in inoculants (Weinberg et al., 2004).

The rice crop residue is lower part of rice crop after being harvested and left at rice field. These residues are abundantly available, and most of them are not be used as livestock feeds and is burned after dried thus causing air pollution. Takahashi et al. (2005) revealed that rice crop residue is potential to be preserved as silage and used as ruminant feeds. However, successful ensiling of rice straw is difficult due to its hollow stem, low water soluble carbohydrates (WSC) and less epiphytic LAB (Cai, 2006). Sugar-rich materials are commonly used as effective additives for ensiling crops that have low WSC. Cassava waste is a solid residu produced from cassava powder with its primary component of starch. Besides, soybean curd residue is a residue resulted from tofu processing and containing high crude protein i.e. $21.8 \pm 4.5 \%$, and therefore it can be used as protein source for livestock (Santoso \& Hariadi, 2009).

The LAB play an important role in silage fermentation and influence silage quality. Under natural circumtances, LAB grows as epiphytic bacteria, however, the population of LAB is usually low and variable with standing crops (Muck, 1990). Thus, addition of LAB inoculant is needed to improve silage quality (Bureenok et al., 2006). In the previous studies, Yahaya et al. (2004); Bureenok et al. (2005); Bureenok et al. (2006) stated that tropical and temperate forages ensiled with addition of epiphytic lactic acid bacteria inoculant resulting good fermentation quality compared to commercial inoculant. Santoso et al. (2009) concluded that fermentative quality of grass silage treated with epiphytic LAB prepared from king grass was better than those prepared from elephant grass. Similar result was reported in other experiment of Antaribaba et al. (2009); Santoso et al. (2011) that king grass silage with addition of epiphytic LAB had good fermentation quality compared to control silage, as indicated by high lactic acid content and in vitro nutrient digestibility, and low $\mathrm{N}$-amonia concentration. Wang et al. (2009) concluded that the effect of LAB from forage crop may be comparable or even better than commercial bacterial culture, because the commercial bacterial does not grow well on the target crop.

Addition of LAB inoculant in silage materials could improve fermentation quality of silage and nutrient digestibility. Thus the experiment was carried out to evaluate the nutritive value and fermentation characteristic of rice crop residue-based silage treated with addition of epiphytic LAB inoculant from king grass extract and a commercial inoculant of L. plantarum.

\section{MATERIALS AND METHODS}

\section{Silage Materials}

Fresh rice crop residue (Oryza sativa var. Mygongga) was obtained from rice field area at Prafi District, Manokwari regency. Soybean curd and cassava waste were collected from small-scale food industry located at Prafi District. King grass was harvested at 50 days of regrowth defoliation from the experimental field of Faculty of Animal Science, Fishery and Marine Science, State University of Papua in Manokwari.

\section{Inoculants Preparation}

The epiphytic LAB inoculant was prepared according to modified of Bureenok et al. (2006) procedure as previously described by Santoso et al. (2009); Santoso et al. (2011). The inoculant was made using $220 \mathrm{~g}$ of fresh king grass or fresh rice crop residue, which was macerated in $1000 \mathrm{ml}$ of distilled water using a high-speed blender for $4 \mathrm{~min}$. The macerated was filtered through two layers of cheesecloths, and $600 \mathrm{ml}$ of filtrate was collected in Erlenmeyer glass containing $18 \mathrm{~g}$ of glucose. The filtrate was mixed well and incubated anaerobically for $48 \mathrm{~h}$ at $30^{\circ} \mathrm{C}$. At the end of $48 \mathrm{~h}$, inoculant was used as source of LAB. The number of LAB inoculant was counted before the experiments by using de Man, Rogosa, and Sharpe (MRS) which were incubated for 3 days at $35{ }^{\circ} \mathrm{C}$ (Bureenok et al., 2006). The commercial L. plantarum was provided by Laboratory of Food Technology, Gadjah Mada University and then prepared by incubation in MRS broth (Difco Laboratories) at $30^{\circ} \mathrm{C}$ for $48 \mathrm{~h}$. LAB strain in king grass extract was isolated, purified and identified using a commercial kit (API 50 $\mathrm{CH}$, bioMérieux, Inc. Durham, NC, USA) according to the manufacturer's recommendation.

\section{Isolation and Purification of LAB}

Briefly, $100 \mathrm{ml}$ of dilution from first step preparation was then placed on MRS agar in triplicates and kept in anaerobic condition using anaerobic jar. They were incubated at $30{ }^{\circ} \mathrm{C}$ until colonies were visible. A single colony from above procedure was chosen and they were sub cultured for two or three times to get purified bacteria. Finally, the purified bacteria were used for identification strain of LAB.

\section{Experiment 1 \\ (Silages Preparation and Treatments)}

Fresh rice crop residue was chopped with a domestic cutter to approximately $2-3 \mathrm{~cm}$ lengths. The chopped rice crop residue (RC), soybean curd residue (SC) and cassava waste $(\mathrm{CW})$ were thoroughly mixed in a $80: 10$ : 
10 ratio (on DM basis) and used as silage material. Four treatments silage were (A) $\mathrm{RC}+\mathrm{SC}+\mathrm{CW}$ as a control; (B) $\mathrm{RC}+\mathrm{SC}+\mathrm{CW}+\mathrm{LAB}$ inoculant from king grass $(2 \%$, $\mathrm{v} / \mathrm{w}) ;(\mathrm{C}) \mathrm{RC}+\mathrm{SC}+\mathrm{CW}+\mathrm{LAB}$ inoculant from king grass $(3 \%, \mathrm{v} / \mathrm{w}) ;(\mathrm{D}) \mathrm{RC}+\mathrm{SC}+\mathrm{CW}+$ L. plantarum inoculant $(2 \%, v / w)$. The inoculants were sprayed onto silage material and subsequently mixed by hand before packing into silos. About $1.5 \mathrm{~kg}$ of silage materials were packed into plastic silos $(295 \times 495 \times 0.06 \mathrm{~mm})$ and stored in room temperature $\left( \pm 28{ }^{\circ} \mathrm{C}\right)$ for 30 days. Each treatment was prepared in 9 replications and opened after 5, 10, and 30 days of ensiling. Samples were collected for preparation of silage extract and sample analyses.

\section{Experiment 2}

\section{(in Vivo Nutrient Digestibility)}

Six Kacang goats (an indigenous breed found in Indonesia) with an initial body weight (BW) of $16.3 \pm 1.8$ $\mathrm{kg}$ were used in a $6 \times 3$ Youden square experiment. Goats were housed in six individual metabolism cages that facilitated separate collection of feces and urine. The experimental diets consisted of (A) elephant grass; (B) rice straw and (C) rice crop residue-based silage supplied twice a day (08:00 and 16:00 h) at a maintenance level of DM intake ( $66 \mathrm{~g} \mathrm{DM} / \mathrm{kgBW}^{0.75} /$ day) as recommended by Kearl (1982). Fresh water and a salt lick were available ad libitum. Before the start of the experiment, goats were dewormed with $2.5 \mathrm{mg} / \mathrm{kg}$ BW of Ascamex. Each period of the experiment lasted 13 days and was comprised of 8 days for diet adaptation and 5 days for digestion trial study. Total fecal excretions by each goat were collected and weighed. Individual feed refusals if any, were collected, weighed daily and samples bulked for analyses. Feces were sub-sampled, bulked and stored at $-15^{\circ} \mathrm{C}$ for subsequent analyses. Chemical analyses of feces samples were done with six replication of each treatment. Goats were weighed full at the beginning and the end of each period.

\section{Chemical Analyses}

Dried samples were used to determine DM, ash and crude protein (CP) according to procedure of AOAC (2005). Procedure of Van Soest et al. (1991) was used to determined concentrations of NDF, acid detergent fiber (ADF) and acid detergent lignin (ADL). NDF was determined without the use of $\alpha$-amylase and sodium sulfite.

A $20 \mathrm{~g}$ of silage was macerated with $70 \mathrm{ml}$ of distilled water and stored at $4{ }^{\circ} \mathrm{C}$ for $24 \mathrm{~h}$. It was then homogenized for $15 \mathrm{~min}$ by using a shaker and filtered through a Whatman No. 1542 filter paper. The filtrate was used for determine of $\mathrm{pH}, \mathrm{VFAs}$, lactic acid and $\mathrm{NH}_{3}-\mathrm{N}$. The $\mathrm{pH}$ value was determined using a $\mathrm{pH}$ meter (Hanna Hi 9025). Concentrations of individual VFAs were analyzed using a gas chromatography (Varian CP-9002 GC, Shimadzu, Japan) equipped with flame ionization detector (FID) and stainless steel column $(1500 \mathrm{~mm} \times 3 \mathrm{~mm}$ i.d). The pressure of nitrogen was 1.25 $\mathrm{kg} / \mathrm{cm}^{2}$. The temperature of injector oven, column oven and detector were 220, 130 and $220{ }^{\circ} \mathrm{C}$, respectively. Concentrations of lactic acid and $\mathrm{NH}_{3}-\mathrm{N}$ were analyzed according to method of Barker \& Summerson (1941); Chaney \& Marbach (1962), respectively. Fleigh Point of the silage were calculated according to formulae as follows : Fleigh Point $=220+(2 \times \mathrm{DM} \%-15)-(40 \times \mathrm{pH})$, where Fleigh Point denote values between 85 and 100, very good quality; 60 and 80, good quality; 55 and 60, moderate quality; 25 and 40, satisfying quality; < 20, worthless (Ozturk et al., 2006).

\section{Statistical Analysis}

Data of fermentation characteristics of silage were subjected to analysis of variance for completely randomized design using GLM procedure of SAS (SAS Institute Inc., Cary, NC) with the model :

$$
Y_{i j}=\mu+\alpha_{i}+\varepsilon_{i j}
$$

where $Y_{i j}$ is the observed value for the $i$ th treatment and $j$ th replicate, $\mu$ is overall mean, $\alpha_{i}$ is treatment effect for the $i$ th treatment, $\varepsilon i j$ is the random error associated with $Y_{i j}$ experimental unit. Data of nutrient digestibility were analyzed using following the model :

$$
Y_{i j k}=\mu+\alpha_{i}+\beta_{j}+\gamma_{k}+\varepsilon_{i j k}
$$

where $Y_{i j k}$ is the observed value for the $i$ th treatment, $j$ th animal, and $k$ th period, $\mu$ is overall mean, $\alpha_{i}$ is treatment effect for the $i$ th treatment, $\beta_{j}$ is animal effect for the $j$ th animal, $\gamma_{k}$ is period effect for the $k$ th period, $\varepsilon_{i j k}$ is the random error associated with $Y_{i j k}$ experimental unit. Duncan's multiple range test was used to identify significant differences between means.

\section{RESULTS AND DISCUSSION}

\section{Characteristics of King Grass Extract}

After $48 \mathrm{~h}$ of anaerobic incubation, LAB number in king grass extract increased by 10 fold and followed by decreasing $\mathrm{pH}$ value from 6.81 to 3.29 (Table 1 ). This result indicate that LAB produced high lactic acid concentration during incubation which resulted in low $\mathrm{pH}$ value. This result is consistent with previous studies by Antaribaba et al. (2009); Santoso et al. (2009); Santoso et al. (2011) that $\mathrm{pH}$ value in king grass extract declined from average of 6.62 to 3.40 after $48 \mathrm{~h}$ of incubation at 30 ${ }^{\circ} \mathrm{C}$. Trend declined $\mathrm{pH}$ value in extracts of grass and legume after $48 \mathrm{~h}$ of incubation have been also reported by Bureenok et al. (2006) and Wang et al. (2009). Two strains LAB found in king grass extract were Lactobacillus plantarum and Lactobacillus brevis.

Table 1. Changes of $\mathrm{pH}$ value and $\mathrm{LAB}$ number in king grass extract before and after $48 \mathrm{~h}$ of incubation

\begin{tabular}{lcc}
\hline & Before incubation & After incubation \\
\hline $\mathrm{pH}$ value & 6.81 & 3.29 \\
$\mathrm{LAB}\left(\times 10^{10} \mathrm{cfu} / \mathrm{ml}\right)$ & 0.30 & 3.00 \\
\hline
\end{tabular}




\section{Chemical Composition and Fermentative Quality of Silage}

The DM content of silages was lower than the value of $30 \%$ for ideal silage as suggested by Chamberlain \& Wilkinson (1996). This was due to rice crop residue mixed by soybean curd residue and cassava waste which has high moisture content i.e. $86.9 \%$ and $82.0 \%$, respectively (Table 2). Relatively high $\mathrm{OM}$ content $(\mathrm{P}>0.05)$ was observed in silage $B$ and $C$ than control silage (A). This may be attributed to carbohydrate degradation to organic acids i.e. acetic, propionic and butyric acids in both silages was lower than silage $A$, as supported by total VFA concentration in both silages. A relative high $\mathrm{CP}$ content $(\mathrm{P}>0.05)$ was observed in silage treated with epiphytic LAB (B and C) and L. plantarum (D) could be due to low degradation of CP to amino acids and ammonia during ensiling. This result is consistent with $\mathrm{NH}_{3}-\mathrm{N}$ concentration in all silages (Table 3). Silages $\mathrm{B}$, $\mathrm{C}$ and $\mathrm{D}$ tended have lower $(\mathrm{P}=0.08)$ ADF concentration than the control silage. It has been reported that activity of cellulase and hemicellulase enzymes was high during ensilage (Yahaya et al., 2004). Similar results were also reported in other experiments using guinea grass and king grass silages (Ando et al., 2006; Antaribaba et al., 2009; Santoso et al., 2009; Santoso et al., 2011).

The fermentation characteristics of rice crop residue-based silage treated with LAB from king grass and L. plantarum inoculants are presented in Table 3. Lactic acid production in silage $\mathrm{C}$ and $\mathrm{B}$ was higher $(\mathrm{P}<0.01)$ than silage $\mathrm{D}$ and $\mathrm{A}$. As compared to control silage (A), lactic acid concentration increased by $41.3 \%, 50.6 \%$, and $24.8 \%$ respectively for silage B, C, and D. High lactic acid concentration in silage treated with epiphytic LAB (B and C) and L. plantarum inoculant (D) followed by lower $(\mathrm{P}<0.01) \mathrm{pH}$ value than control silage $(\mathrm{A})$. McDonald et al. (1991) stated that reducing $\mathrm{pH}$ silage prevented the growth of undesirable microbes e.g. listeria, clostridia, enterobacteriaceae and moulds. However, $\mathrm{pH}$ value of all silage are still above than ideal silage $\mathrm{pH}$ of 4.0 to 4.5 as suggested by Chamberlain \& Wilkinson (1996). Higher $\mathrm{pH}$ value in silage could be attributed to limited of water soluble carbohydrate content, thus resulted in low lactic acid concentration produced by LAB. This result was similar with previoulsy studied by Cao et al. (2010) whole crop rice silage added with L. plantarum

Table 2. Chemical composition (\% of DM) of rice crop residue-based silage

\begin{tabular}{lrrrrrrr}
\hline & \multicolumn{3}{c}{ Silages } & & \multirow{2}{*}{ SEM } & P \\
\cline { 2 - 6 } & A & B & C & D & & 0.30 & $<0.01$ \\
Dry matter (DM) & $20.4^{\mathrm{B}}$ & $20.5^{\mathrm{B}}$ & $21.6^{\mathrm{AB}}$ & $22.4^{\mathrm{A}}$ & & 0.25 & 0.66 \\
Organic matter & 82.0 & 81.8 & 82.2 & 82.2 & & 0.20 & 0.19 \\
Crude protein & 5.3 & 5.7 & 5.7 & 6.0 & 6.5 & 1.10 & 0.20 \\
NDF & 69.7 & 66.7 & 67.8 & 66.5 & & 0.99 & 0.08 \\
ADF & 60.8 & 57.7 & 57.8 & 56.7 & & \\
\hline
\end{tabular}

Note: Means in the same row with different superscript differ significantly $(\mathrm{P}<0.01)$. A=rice crop residue + soybean curd residue + cassava waste (80:10:10, DM basis); B=rice crop residue + soybean curd residue + cassava waste (80:10:10, DM basis) + LAB inoculant from king grass (2\%, v/w); $\mathrm{C}=$ rice crop residue + soybean curd residue + cassava waste (80:10:10, DM basis) + LAB inoculant from king grass ( $3 \%$, v/w); $\mathrm{D}=$ rice crop residue + soybean curd residue + cassava waste (80:10:10, DM basis) + L. plantarum (2\%, v/w). NDF: neutral detergent fiber; ADF: acid detergent fiber; SEM: standard error of the mean.

Table 3. Fermentation characteristics of rice crop residue-based silage

\begin{tabular}{|c|c|c|c|c|c|c|}
\hline & \multicolumn{4}{|c|}{ Silages } & \multirow{2}{*}{ SEM } & \multirow{2}{*}{$\mathrm{P}$} \\
\hline & $\mathrm{A}$ & B & $\mathrm{C}$ & $\mathrm{D}$ & & \\
\hline $\mathrm{pH}$ & $5.10^{\mathrm{a}}$ & $4.67^{\mathrm{b}}$ & $4.61^{\mathrm{b}}$ & $4.72^{\mathrm{b}}$ & 0.09 & 0.02 \\
\hline Lactic acid (g/kg DM) & $31.0^{\mathrm{C}}$ & $43.8^{\mathrm{A}}$ & $46.7^{\mathrm{A}}$ & $38.7^{\mathrm{B}}$ & 1.01 & $<0.01$ \\
\hline NH3-N(g/kg DM) & 4.3 & 3.9 & 3.2 & 3.1 & 0.36 & 0.14 \\
\hline Acetic acid (g/kg DM) & $9.93^{\mathrm{b}}$ & $18.9^{\mathrm{a}}$ & $19.0^{\mathrm{a}}$ & $16.6^{\mathrm{ab}}$ & 2.05 & 0.04 \\
\hline Propionic acid (g/kg DM) & $1.1^{\mathrm{B}}$ & $3.6^{\mathrm{A}}$ & $2.9^{\mathrm{AB}}$ & $2.9^{\mathrm{AB}}$ & 0.38 & $<0.01$ \\
\hline Butyric acid (g/kg DM) & 3.5 & 3.3 & 3.1 & 2.6 & 0.64 & 0.81 \\
\hline Total VFA(g/kg DM) & $14.5^{\mathrm{b}}$ & $25.9^{\mathrm{a}}$ & $25.0^{\mathrm{a}}$ & $22.2^{\mathrm{ab}}$ & 2.51 & 0.04 \\
\hline Fleigh Point & 45.7 & 59.3 & 63.8 & 56.7 & 4.14 & 0.07 \\
\hline
\end{tabular}

Note: Means in the same row with different superscript differ significantly ( $\left.{ }^{\mathrm{a}-\mathrm{b}} \mathrm{P}<0.05 ;{ }^{\mathrm{A}-\mathrm{B}} \mathrm{P}<0.01\right)$. A =rice crop residue + soybean curd residue + cassava waste (80:10:10, DM basis); $B=$ rice crop residue + soybean curd residue + cassava waste (80:10:10, DM basis) + LAB inoculant from king grass $(2 \%, v / w) ; C=$ rice crop residue + soybean curd residue + cassava waste $(80: 10: 10, \mathrm{DM}$ basis $)+$ LAB inoculant from king grass $(3 \%$, v/w); $\mathrm{D}=$ rice crop residue + soybean curd residue + cassava waste (80:10:10, DM basis) + L. plantarum (2\%, v/w). VFA: volatile fatty acids; SEM: standard error of the mean. 
had higher lactic acid concentration than molasses and control silage. Chamberlain (1987) stated that high lactic acid concentration of silage has beneficial for ruminant because Megasphaera elsdenii metabolizes lactic acid to propionic acid and then is used as gluconeogenesis precursor. Change in lactic acid concentration during fermentation of rice crop residue based silage is shown in Figure 1. A rapid increase in lactic acid concentration occured in silage $\mathrm{C}$ during 10 days of ensiling. Furthermore, lactic acid concentration in all silages was slightly declined up to 30 days of ensiling.

Concentrations of $\mathrm{NH}_{3}-\mathrm{N}$ and butyric acid were similar $(\mathrm{P}>0.05)$ among silage treatments. Silages $\mathrm{B}$ and $C$ had higher $(P<0.01)$ concentration of acetic acid than silage A. This result indicates that activity of heterofermentative $\mathrm{LAB}$ in both silages $\mathrm{B}$ and $\mathrm{C}$ was higher than in silage A. McDonald et al. (1991) revealed that during ensiling, hexose is fermented to lactid acid and other products i.e. ethanol and acetic acid. In our research, although there was no difference among silages on butyric acid concentration, silage $A$ had relative higher butyric acid than other silages. That results indicate that clostridia bacteria was more active in control silage (A) than silage treated with epiphytic LAB or L. plantarum inoculant. According to Chamberlain \& Wilkinson (1996), secondary fermentation occurs insufficient acid is produced by the primary fermentation to reduce the $\mathrm{pH}$ to below a critical level of about 4.5. The bacteria responsible for secondary fermentations are mainly the clostridia. These bacteria may convert lactic acid to butyric, or the may degrade proteins, peptides and amino acids to amines and ammonia. McDonald et al. (1987) also reported that butyric acid is produced by saccharolytic clostridia i.e. Clostridium butyricum. The total VFA concentration tended to decrease in silages added with $\mathrm{LAB}$ inoculant than control silage. The result indicates that additon of LAB inoculant to rice crop residue could improve fermentative quality of silage. Chamberlain \& Wilkinson (1996) stated that the VFA comprise acitic acid, propionic acid, butyric acid and other acids. The production of these acids is reflection of an inefficient

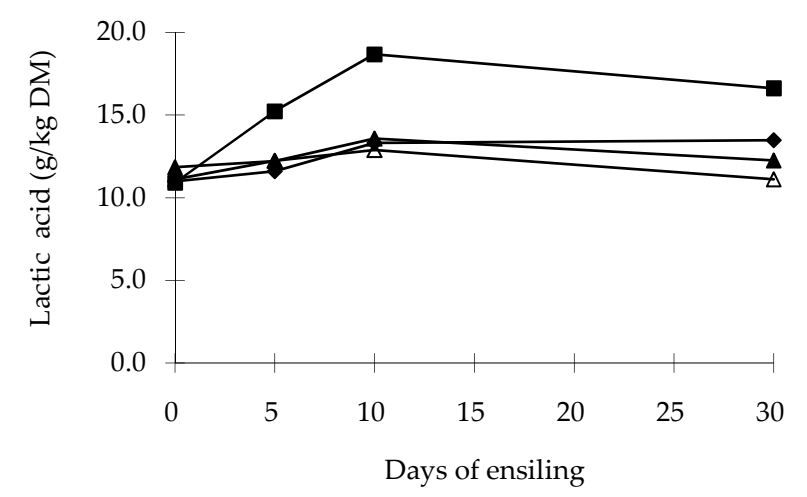

fermentation or of secondary fermentation of lactic acid to butiryc acid and degradation of amino acids to ammonia with the production of amino acid from skeleton of the amino acid. In the present study, the proportion of VFA to total acid was $31.9 \%, 37.2 \%, 34.9 \%$, and $36.5 \%$, respectively for silage $A, B, C$, and $D$. The result indicates that fermentation of silage $A$ was more efficient than silage B, C, and D. However, the values found in this study are still above than ideal value of $20 \%$ as recommended by Chamberlain \& Wilkinson (1996).

Fleigh point in silage $C$ was relatively higher than other silages, suggesting that silage treated with epiphytic LAB prepared from king grass at level of 3\% $(\mathrm{v} / \mathrm{w})$ had better fermentative quality as compared to other silages. In addition, Fleigh point found in the present study was higher than the value of 41.7 in king grass silage as reported by Santoso et al. (2009), but it was lower than Fleigh point of 72.83 for alfalfa-maize silage mixture (Ozturk et al., 2006).

\section{Chemical Composition and in Vivo Nutrient Digestibility}

The OM content in rice crop residue-based silage was higher than rice straw (Table 4). This can be caused by rice crop residue-based silage in this experiment was added soybean curd and cassava containing OM 96.4\% and $98.6 \%$, respectively. Elephant grass containing proteins two times higher than rice straw and rice-based crop residue silage.

Table 5 shows DM, OM, and CP digestibility by goats. The DM digestibility value in goats fed elephant grass (A) and rice crop residue-based silage (B) was higher $(P<0.01)$ than those fed rice straw $(C)$. In this experiment, however, DM digestibility value in goats fed

Table 4. Chemical composition (\%) of experimental feeds

\begin{tabular}{lccc}
\hline & \multicolumn{3}{c}{ Feeds } \\
\cline { 2 - 4 } & $\mathrm{A}$ & $\mathrm{B}$ & $\mathrm{C}$ \\
\hline Dry matter & 20.4 & 90.5 & 21.7 \\
Organic matter & 89.3 & 77 & 82.3 \\
Crude protein & 14.9 & 7.1 & 7.5 \\
\hline
\end{tabular}

Note: $\mathrm{A}=$ king grass; $\mathrm{RS}=$ rice straw; $\mathrm{RCS}=$ rice crop residue-based silage

Table 5. Nutrients digestibility (\%) in goats fed elephant grass, rice straw and rice crop residue-based silage

\begin{tabular}{lccccc}
\hline \multirow{2}{*}{ Digestibility } & \multicolumn{3}{c}{ Feeds } & SEM & P \\
\cline { 2 - 4 } & A & B & C & & \\
\hline Dry matter & $60.5^{\mathrm{A}}$ & $51.4^{\mathrm{B}}$ & $59.9^{\mathrm{A}}$ & 1.24 & $<0.01$ \\
Organic & $65.9^{\mathrm{A}}$ & $55.0^{\mathrm{C}}$ & $60.7^{\mathrm{B}}$ & 0.88 & $<0.01$ \\
matter & & & & & \\
Crude protein & $70.9^{\mathrm{A}}$ & $42.6^{\mathrm{C}}$ & $51.6^{\mathrm{B}}$ & 1.30 & $<0.01$ \\
\hline
\end{tabular}

Note: Means in the same row with different superscript differ significantly $(\mathrm{P}<0.01) . \mathrm{A}=$ Elephant grass; $\mathrm{B}=$ Rice straw; $\mathrm{C}=$ Rice crop residue based-silage. 
elephant grass and rice-based crop residue silage was similar; suggesting that preservation of rice crop residue into silage is an effective way to improve the digestibility. Dry matter digestibility value in goats fed rice crop residue-based silage increased by $16.5 \%$ compared to fed rice straw. Organic matter and CP digestibility values in goats fed elephant grass were higher $(\mathrm{P}<0.01)$ than those fed a rice-based crop residue silage and rice straw. High $\mathrm{OM}$ and $\mathrm{CP}$ digestibility values in goats fed a elephant grass due to grass contains CP more than two times compared to hay and rice crop residue-based silage. These conditions cause the activity of rumen microbes such as bacteria and protozoa increased and subsequently followed by increases in the process of degradation and fermentation of feed. As compared to rice straw, the digestibility of $\mathrm{OM}$ and $\mathrm{CP}$ in goats fed rice crop residue-based silage increased by 10.4 and $21.1 \%$, respectively. This result was supported by previous study by Ando et al. (2006) that addition of LAB increased the digestibility of dry matter, organic matter, and crude protein of guinea grass silage. However, Takahashi et al. (2005) reported that there was no differences in digestibility of DM, OM, and CP between sheep fed whole crop rice silage with or without the addition of fermented juice of epiphytic LAB from rice crop.

\section{CONCLUSION}

Addition of epiphytic LAB inoculant extracted from king grass to rice crop residue enhanced lactic acid concentration by $38.1 \%$ compared to control silage. Rice crop residue-based silage with addition of LAB inoculant from king grass had better fermentation quality than those ensiled with addition of LAB inoculant from rice crop residue. Feeding rice crop residue silage-based to goats significantly improved digestibility of DM, OM, and $\mathrm{CP}$ compared to rice straw.

\section{ACKNOWLEDGEMENT}

This research was funded by the Indonesian Ministry of Agriculture through KKP3T program (Contract no. 1137/LB.620/I.1/4/2010).

\section{REFERENCES}

Ando, S., M. Ishida, S. Oshio \& O. Tanaka. 2006. Effects of isolated and commercial lactic acid bacteria on the silage quality, digestibility, voluntary intake and ruminal fluid haracteristics. Asian-Aust. J. Anim. Sci. 19: 386-389.

Antaribaba, M. A., N. K. Terro, B. Tj. Hariadi, \& B. Santoso. 2009. Effect of level of lactic acid bacteria inoculum prepared from king grass extract on fermentative quality of king grass silage. J. Anim Sci. Vet. 14: 278-283.

[AOAC] Association of Official Analytical Chemists. 2005. Official Methods of Analysis. 17 ${ }^{\text {th }} \mathrm{Ed}$. Washington: AOAC International.

Barker, S. B. \& W. H. Summerson. 1941. The colorimetric determination of lactic acid in biology material. J. Biol. Chem. 138: 535-554.

Bureenok, S., T. Namihira, S. Mizumachi, Y. Kawamoto, \& T. Nakada. 2006. The effect of epiphytic lactic acid bacteria with or without different byproduct from defatted rice bran and green tea waste on napiergrass (Pennisetum pur- pureum Shumach) silage fermentation. J. Sci. Food Agric. 86: 1073-1077. DOI: 10.1002/jsfa.2458.

Bureenok, S., T. Namihira, Y. Kawamoto, \& T. Nakada. 2005. Additive effects of fermented juice of epiphytic lactic acid bacteria on fermentative quality of guineagrass (Panicum maximum Jacq.) silage. Grassland Sci. 51: 243-248. DOI: 10.1111/j.1744-697x.2005.00032.x.

Cai, Y. M. 2006. Development of lactic acid bacteria inoculant for whole crop rice silage in Japan. In: International Symposium on Production and Utilization of Whole Crop Rice for Feed, Busan, Korea. pp. 85-89.

Cao, Y., T. Takahashi, K. Horiguchi, \& N. Yoshida. 2010. Effect of adding lactic acid bacteria and molasses on fermentation quality and in vitro ruminal digestion of total mixed ration silage prepared with whole crop rice. Grassl. Sci. 56: 19-25. DOI: 10.1111/j.1744-697x.2009.00168.x

Chamberlain, A. T. \& J. M. Wilkinson. 1996. Feeding the Dairy Cow. Chalcombe Publications, Lincoln, UK.

Chamberlain, D. G. 1987. The silage fermentation in relation to the utilization of the nutrients in the rumen. Process Biochem. 22: 60-63.

Chaney, A. L. \& E. P. Marbach. 1962. Modified reagents for determination of urea and ammonia. Clin Chem 8: 130-132.

Gao, L. J., H. Y. Yang, X. F. Wang, Z. Y. Huang, M. Ishii, Y. Igarashi, \& Z. J. Cui. 2008. Rice straw fermentation using lactic acid bacteria. Biores. Tech. 99:2742-2748

Kearl, L. C. 1982. Nutrient Requirements of Ruminants in Developing Countries. International Feedstuff Institute, Utah State University, Logan, UT, USA.

McDonald, P., A. R. Hunderson, \& S. J. E. Heron. 1991. The Biochemistry of Silage. $2^{\text {nd }}$ ed. Cambrian Printers Lt. Aberystwyth.

McDonald, P., R. A. Edwards, \& J. F. D. Greenhalgh. 1987. Animal Nutrition. 4th edition. Longma Group Ltd. Hongkong.

Muck, R. E. 1990. Prediction of lactic acid bacteria numbers on lucerne. Grass Forage Sci. 45: 273-280.

Ozturk, D., M. Kizilsimsek, A. Kamalak, O. Canbolat, \& C. O. Ozkan. 2006. Effects of ensiling alfalfa with whole-crop maize on the chemical composition and nutritive value of silage mixtures. Asian-Aust. J. Anim. Sci.. 19:526-532.

Nishino, N., H. Wada, M. Yoshida, \& H. Shiota. 2004. Microbial counts, fermentation products, and aerobic stability of whole crop corn and a total mixed ration ensiled with and without inoculation of Lactobacillus casei or Lactobacillus buchneri. J. Dairy Sci. 87:2563-2570.

Santoso, B. \& B. Tj. Hariadi. 2009. Evaluation of nutritive value and in vitro methane production of feedstuffs from agricultural and food industry by-products. J. Indon. Trop. Anim. Agric. 34: 190-196.

Santoso, B. B. Tj. Hariadi, H. Manik, \& H. Abubakar. 2009. Kualitas rumput unggul tropika hasil ensilase dengan aditif bakteri asam laktat dari ekstrak rumput terfermentasi. Med. Pet. 32: 138-145.

Santoso, B., B. Tj., Hariadi, H. Manik, \& H. Abubakar. 2011. Silage quality of king grass (Pennisetum purpureophoides) treated with epiphytic lactic acid bacteria and tannin of acacia. Med. Pet. 34: 140-145. DOI: 10.5398/med.pet. 2011.34.2.140

Takahashi, T., K. Horiguchi, \& M. Goto. 2005. Effect of crushing rice and the addition of fermented juice of epiphytic lactic acid bacteria on the fermentation quality of whole crop rice silage, and its digestibility and rumen fermentation status in sheep. Anim. Sci. J. 76: 353-358.

Van Soest, P. J., J. B. Robertson, \& B. A. Lewis. 1991. Methods for dietary fiber, neutral detergent fiber, and nonstarch polysaccharides in relation to animal nutrition. J. Dairy Sci. 74: 3583-3597.

Wang, J., J. Q. Wang, H. Zhou, \& T. Feng. 2009. Effects of ad- 
dition of previously fermented juice prepared from alfalfa on fermentation quality and protein degradation of alfalfa silage. Anim. Feed Sci. Technol. 151: 280-290. DOI: 10.1016/ j.anifeedsci.2009.03.001.

Weinberg, Z. G., R. E. Muck, P. J. Weimer, Y. Chen, \& M. Gamburg. 2004. Lactic acid bacteria used in inoculants for silage as a probiotics for ruminants. Appl. Biochem. Biotech. 118: $1-10$.
Yahaya, M. S., M. Goto, W. Yimiti, B. Smerjai, \& Y. Kuwamoto. 2004. Evaluation of fermentation quality of a tropical and temperate forage crops ensiled with additives of fermented juice of epiphytic lactic acid bacteria (FJLB). Asian-Aust. J. Anim. Sci. 17: 942-946. 